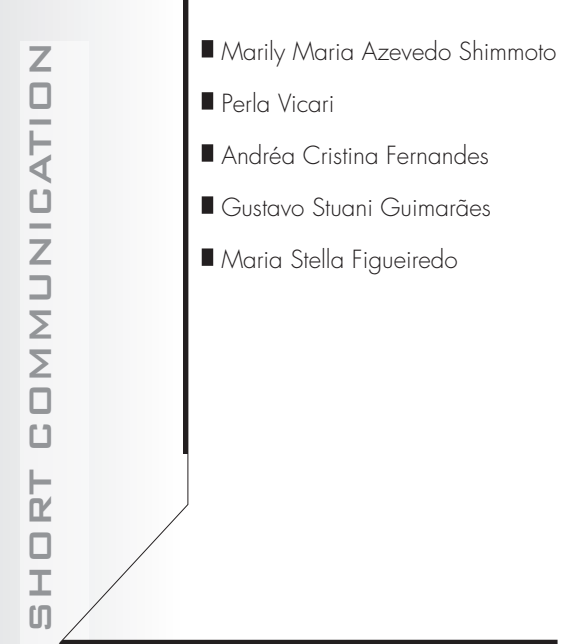

ABSTRACT

CONTEXT AND OBJECTIVE: Acquired fetal hemoglobin (HbF) elevation has been implicated as a prognostic factor in dyserythropoietic disorders. Our objectives were to examine acquired $\mathrm{HbF}$ increases in aplastic anemia (AA) and paroxysmal nocturnal hemoglobinuria (PNH) patients, and to evaluate whether there is an association between the presence of $X \mathrm{mnl}$ and $5^{\prime}$ hypersensitive site locus control region (LCR-HS2) polymorphisms and the $\mathrm{HbF}$ levels.

DESIGN AND SETTING: Cross-sectional study at the Hematology and Blood Transfusion Service of Universidade Federal de São Paulo - Escola Paulista de Medicina.

METHODS: We studied a group of 37 patients with $\mathrm{AA}$ and/or PNH. Polymerase chain reaction (PCR) and enzymatic digestion were utilized to analyze Xmnl polymorphisms; and $P C R$, cloning and automated sequencing for the HS2 polymorphisms.

RESULTS: The mean $\mathrm{HbF}$ level was $2.32 \%$, but there was no significant difference in $\mathrm{HbF}$ level between the AA and PNH groups $(p=0.46)$. $\mathrm{HbF}$ levels of less than $1.0 \%$ showed a significant correlation with absence of the $\mathrm{Xmnl}(+)$ polymorphism $(p=0.02)$. The presence of the $X m n l$ allele was greater in the AA group $(p=0.007)$.

CONCLUSIONS: $\mathrm{Xmnl}$ polymorphism absence reduction is associated with acquired $\mathrm{HbF}$ elevation. Further studies are required to confirm these observations and make treatment, prognosis and survival comparisons.

KEY WORDS: Polymorphism (Genetics). Aplastic anemia. Paroxysmal hemoglobinuria. Fetal hemoglobin. Polymerase chain reaction.

\title{
XmnI polymorphism is associated with fetal hemoglobin levels in hypoplastic syndromes
}

\author{
Hematology and Blood Transfusion Service, Universidade Federal de \\ São Paulo - Escola Paulista de Medicina, São Paulo, Brazil
}

\begin{abstract}
INTRDDUCTION
There are several genetically different conditions under which higher levels of fetal hemoglobin $(\mathrm{HbF})$ synthesis can persist into adult life. The clinical importance of the persistence of $\mathrm{HbF}$ expression in adults in relation to certain dyserythropoietic diseases remains controversial. However, acquired $\mathrm{HbF}$ elevation has been implicated as a prognostic factor in myelodysplastic syndrome (MDS) and aplastic anemia (AA)., ${ }^{1,2}$

There are many factors that could change the level of $\mathrm{HbF}$ in adults, such as age, sex, polymorphisms, $\beta$-globin locus control region (LCR) and $\mathrm{HbF}$ persistence. Among the polymorphic genetic markers of the $\beta$-globin gene cluster, the XmnI polymorphism, a common $\mathrm{C} \rightarrow \mathrm{T}$ variation at position -158 of the ${ }^{\mathrm{G}} \gamma$ globin gene, and a set of sequence variations in the 5' hypersensitive site (HS2) of the LCR have been associated with increased $\mathrm{HbF}$ levels in normal individuals, and in $\beta$-thalassemia and sickle cell anemia patients. ${ }^{2,3}$
\end{abstract}

口BJECTIVE

Our objectives were to examine acquired $\mathrm{HbF}$ increases in $\mathrm{AA}$ and paroxysmal nocturnal hemoglobinuria $(\mathrm{PNH})$ patients, and to evaluate whether there is an association between the presence of XmnI and 5' hypersensitive site locus control region (LCR-HS2) polymorphisms and the HbF levels.

MATERIAL AND METHODS

Setting. This was a cross-sectional study carried out within the Hematology and Blood Transfusion Service of Escola Paulista de Medicina, Universidade Federal de São Paulo, São Paulo, Brazil.

Study plan. Thirty-seven patients were included in this study: $27 \mathrm{AA}$ patients (13 females and 14 males) with a mean age of 39.44 years (range from 15 to 73 ); and $10 \mathrm{PNH}$ patients ( 5 females and 5 males) with a mean age of 48.10 years (range from 22 to 81 ).

Hematological and hemoglobin analysis. Hematological indices were determined using an automated cell counter. $\mathrm{HbF}$ was measured by alkali denaturation. The diagnoses of AA and $\mathrm{PNH}$ were based on clinical and laboratory features, including bone marrow biopsy, Ham's test and flow cytometry.

DNA studies. The presence of $\mathrm{XmnI}$ polymorphism of the ${ }^{\mathrm{G}} \gamma$ gene was established by means of the polymerase chain reaction, followed by digestion with XmnI. The nucleotide sequence of the LCR-HS2 region was determined by an allele-specific sequencing procedure. $^{3}$

Statistical analysis. All the results were investigated by statistical comparison using the Fisher test.

Ethics. This study was approved by the Ethical Committee of Universidade Federal de São Paulo — Escola Paulista de Medicina (Unifesp-EPM).

RESULTS

The percentages of patients with elevated $\mathrm{HbF}$ were $59 \%$ in the AA group and $40 \%$ in the $\mathrm{PNH}$ group. The mean $\mathrm{HbF}$ level in our study was $2.32 \%$ (standard deviation, SD: 2.47 ). There was no significant difference in $\mathrm{HbF}$ levels between the $\mathrm{AA}$ and PNH groups, which were 2.58 and $1.62 \%$ respectively $(\mathrm{p}=0.46)$.

The time when the disease was diagnosed was unrelated to the HbF level. Similarly, no correlation was observed between length of time with the disease and XmnI polymorphism.

Analysis of DNA from both groups showed that there were twelve $(44.45 \%) \mathrm{XmnI}$ heterozygotes and three (11.12\%) XmnI homozygotes in the AA group; and one (10.00\%) heterozygote and one (10.00\%) homozygote 
in the PNH group. The presence of the XmnI allele was significantly higher in the AA group $(\mathrm{p}=0.007)$ (Table 1). The HbF level was compared with presence or absence of the XmnI allele, and it was found that HbF levels of less than $1.0 \%$ had a significant correlation with absence of the polymorphism ( $\mathrm{p}=0.02)$.

The presence of LCR-HS2 polymorphism was observed in only one patient with AA. The patient was an African-Brazilian man with AA, presenting XmnI (-) and $\mathrm{HbF}$ of $6.2 \%$. The polymorphism observed was the same as the Benin haplotype described in sickle cell disease, which could be associated with the patient's ethnic group.

DISCUSSIRN

Elevated expression of $\mathrm{HbF}$ substantially benefits patients with $\beta$-globin disorders. ${ }^{1}$ On the other hand, increased HbF levels in acquired hemopathy has been associated with a better prognosis. ${ }^{1,2}$

In our study, the HbF level was considerably higher than expected, as was the frequency of patients with elevated $\mathrm{HbF}$. The presence of hereditary persistence of fetal hemoglobin in Brazil has been shown to be approximately $0.01 \%$, while we observed $59 \%$ and $40 \%$ in the AA and $\mathrm{PNH}$ patients, respectively. ${ }^{4}$ These data confirm the association between elevated $\mathrm{HbF}$ level and hematopoietic stress that was described previously. ${ }^{2}$

Although there is a need for better understanding of the meaning of the presence of $\mathrm{HbF}$ in adults, few reports have evaluated the importance of XmnI and LCR-HS2 polymorphisms in populations without hemoglobin disorders. ${ }^{1-3}$ We showed a XmnI polymorphism rate of $45.94 \%$ in our sample, with significant correlation with the $\mathrm{HbF}$ level. These results are consistent with previous Brazilian work on AA that showed higher ${ }^{\mathrm{G}} \gamma$ values with higher $\mathrm{HbF}$ levels in bone marrow failure syndromes. ${ }^{5}$ However, no correlation with the length of time since the diagnosis was found.

CONCLUSIONS

We conclude that XmnI polymorphism is probably implicated in acquired $\mathrm{HbF}$ elevation in hypoplastic syndromes. Further studies are required to confirm these observations and make treatment, prognosis and survival comparisons with regard to these hematological disorders.

Table 1. Xmnl allele polymorphism (-158 ${ }^{\mathrm{G}} \gamma$ allele C/T polymorphism) analysis according to aplastic anemia group (AA) and paroxysmal nocturnal hemoglobinuria group $(\mathrm{PNH}) ; p=0.007$

\begin{tabular}{lcccccc} 
& \multicolumn{2}{c}{ Xmnl (+) } & & \multicolumn{3}{c}{ Xmnl (-) } \\
\cline { 2 - 3 } Disease & $\mathbf{n}$ & $(\%)$ & & $\mathbf{n}$ & $(\%)$ & Total \\
\hline PNH & 3 & $(4 \%)$ & & 17 & $(23 \%)$ & $20(27 \%)$ \\
AA & 28 & $(38 \%)$ & & 26 & $(35 \%)$ & $54(73 \%)$ \\
Total & 31 & $(42 \%)$ & & 43 & $(58 \%)$ & $\mathbf{7 4}(100 \%)$ \\
\hline
\end{tabular}

$C=$ cytosine $T$ = thymine
1. Mendek-Czajkowska E, Stomkowski M, Zdebska E, et al. Hemoglobin $\mathrm{F}$ in primary myelofibrosis and in myelodysplasia. Clin Lab Haematol. 2003;25(5):289-92.

2. Kudo $\mathrm{S}$, Harigae $\mathrm{H}$, Watanabe $\mathrm{N}$, et al. Increased $\mathrm{HbF}$ levels in dyserythropoiesis. Clin Chim Acta. 2000;291(1):83-7.

3. Merghoub T, Perichon B, Maier-Redelsperger M, et al. Dissection of the association status of two polymorphisms in the

\section{AUTHOR INFORMATION}

Marily Maria Azevedo Shimmoto, BSc, MSc. Biologist, Hematology and Blood Transfusion Service, Universidade Federal de São Paulo - Escola Paulista de Medicina, São Paulo, Brazil.

Perla Vicari, MD. Hematologist, postgraduate student at Hematology and Blood Transfusion Service Universidade Federal de São Paulo - Escola Paulista de Medicina, São Paulo, Brazil.

Andréa Cristina Fernandes, BSc, MSc. Biomedical scientist, Hematology and Blood Transfusion Service, Universidade Federal de São Paulo - Escola Paulista de Medicina, São Paulo, Brazil.

Gustavo Stuani Guimarães, BSc. Biomedical scientist in the Discipline of Endocrinology, Universidade Federal de São Paulo - Escola Paulista de Medicina, São Paulo, Brazil.

Maria Stella Figueiredo, MD, PhD. Hematologist and Professor, Hematology and Blood Transfusion Service, Universidade Federal de São Paulo - Escola Paulista de Medicina, São Paulo, Brazil.

\section{Address for correspondence}

Perla Vicari

Universidade Federal de São Paulo - Hematology and Blood Transfusion Service Rua Botucatu, 740 - 3o andar

São Paulo (SP) - Brasil - CEP 04023-900

Tel. (+55 11) 5576-4240 - Fax (+55 11) 5571-8806

E-mail: perlavicari@hemato.epm.br

Copyright (c) 2006, Associação Paulista de Medicina beta-globin gene cluster with variations in F-cell number in non-anemic individuals. Am J Hematol. 1997;56(4):239-43.

4. Zago MA, Costa FF, Tone LG, Bottura C. Hereditary hemoglobin disorders in a Brazilian population. Hum Hered. 1983;33(2):125-9.

5. Zago MA. G gamma-levels of the $\mathrm{HbF}$ of patients with bone marrow failure syndromes. Braz J Med Biol Res. 1987;20(3-4):363-8.
Acknowledgments: The authors thank Dr. Ismael D. C. G. da Silva and Dr. Rui M. B. Maciel for their valuable contribution. Sources of funding: This work was supported by grants from Fapesp (00/06733-0)

Conflicts of interest: None

Date of first submission: December 30, 2004

Last received: May 9, 2006

Accepted: May 9, 2006

RESUMロ

Polimorfismo Xmnl está associado com os níveis de hemoglobina fetal em hipoplasias medulares

CONTEXTO E OBJETIVO: $O$ aumento adquirido da hemoglobina fetal (HbF) já foi implicado como fator prognóstico em distúrbios diseritropoiéticos. Nossos objetivos foram de examinar elevações adquiridas na $\mathrm{HbF}$ em pacientes com anemia aplástica (AA) e hemoglobinúria paroxística noturna (PNH), e de avaliar se há associação entre a presença de polimorfismos Xmnl e de região de controle de locus gênico $5^{\prime}$ (LCR-HS2) e os níveis de HbF.

TIPO DE ESTUDO E LOCAL: Estudo longitudinal no Serviço de Hematologia e Transfusão de Sangue da Universidade Federal de São Paulo - Escola Paulista de Medicina.

MÉTODOS: Estudamos um grupo de 37 pacientes com AA e/ou PNH. Reação de polimerase em cadeia (PCR) e digestão enzimática foram usadas para analisar polimorfismos Xmnl; e PCR para clonagem e sequenciamento automático dos polimorfismos HS2.

RESULTADOS: $\bigcirc$ nível médio de $\mathrm{HbF}$ foi de 2,32\%, mas não houve diferença significativa entre o nível de $\mathrm{HbF}$ dos pacientes $\mathrm{AA}$ e PNH $(p=0.46)$. Os níveis de $\mathrm{HbF}$ menores que $1,0 \%$ mostraram correlação estatisticamente significativa com ausência do polimorfismo Xmnl (+) ( $p=0.007)$.

CONCLUSÕES: Ausência de polimorfismo Xmnl está associado com diminuição de HbF. Mais estudos são necessários para confirmar estas observações e fazer comparações sobre tratamento, prognóstico e sobrevida.

PALAVRAS-CHAVE: Polimorfismo (Genética). Anemia aplástica. Hemoglobinúria paroxística. Hemoglobina fetal. Reação em cadeia da polimerase. 